RESEARCH PAPER

\title{
Tobacco industry influence on the definition of tobacco related disorders by the American Psychiatric Association
}

\author{
M D Neuman, A Bitton, S A Glantz
}

Tobacco Control 2005;14:328-337. doi: 10.1136/tc.2004.010512

See end of article for authors' affiliations

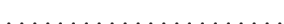

Correspondence to: Professor Stanton A Glantz, PhD, Room 366 Library, 530 Parnassus Avenue, University of California, San Francisco, CA 94143-1390, USA glantz@medicine.ucsf.edu

Received 3 November 2004

Accepted 24 April 2005
Objective: The Diagnostic and statistical manual of mental disorders, third edition (DSM-III), published by the American Psychiatric Association (APA) in 1980, included the first official definitions by the APA of tobacco dependence and tobacco withdrawal. Tobacco industry efforts to influence the DSM-III were investigated.

Method: Searches of previously secret tobacco industry documents, primarily the University of California San Francisco Legacy Tobacco Documents Library and British American Tobacco collections. Additional information was collected through discussions with editors of DSM-III, and library and general internet searches.

Results: The tobacco companies regarded the inclusion of tobacco dependence as a diagnosis in DSM-III as an adverse event. It worked to influence the content of the DSM-III and its impact following publication. These efforts included public statements and private lobbying of DSM-III editors and high ranking APA officers by prominent US psychiatrists with undisclosed ties to the tobacco industry. Following publication of DSM-III, tobacco companies contracted with two US professors of psychiatry to organise a conference and publish a monograph detailing controversies surrounding DSM-III.

Conclusions: The tobacco industry and its allies lobbied to narrow the definition of tobacco dependence in serial revisions of DSM-III. Following publication of DSM-III, the industry took steps to try to mitigate its impact. These actions mirror industry tactics to influence medical research and policy in various contexts worldwide. Such tactics slow the spread of a professional and public understanding of smoking and health that otherwise would reduce smoking, smoking induced disease, and tobacco company profits.
$\mathrm{T}$ he 1988 US Surgeon General's report concluded that cigarettes and other forms of tobacco are addicting as a result of their nicotine content and that the processes determining tobacco addiction "are similar to those that determine addiction to drugs such as heroin and cocaine". ${ }^{1}$ The tobacco industry has been aware of the addictive properties of tobacco products since the 1960s. ${ }^{23}$ For example, in 1963, Addison Yeaman, vice president and general counsel of Brown and Williamson Tobacco, wrote to other managers describing the results of internal industry research on nicotine that "...nicotine is addictive. We are, then, in the business of selling nicotine, an addictive drug effective in the release of stress mechanisms". ${ }^{4}$ In spite of this longstanding internal recognition of nicotine addiction, the members of the tobacco industry have made numerous efforts to publicly deny the addictive nature of their product ${ }^{3}$ and prevent changes in the way that the medical profession and health insurers would view the need for "treatment" of nicotine addiction.

In 1980, tobacco dependence was officially recognised for the first time in the American Psychiatric Association (APA) by its inclusion in the third edition of the Diagnostic and statistical manual of mental disorders (DSM-III). The first two editions of the DSM, published in $1952^{5}$ and $1968,{ }^{6}$ were not comprehensive listings of all psychiatric diagnoses ${ }^{7}$ and neither manual recognised tobacco related disorders as psychiatric diagnoses. In creating DSM-III, the APA sought to "embrace as many conditions as are commonly seen by practicing clinicians" and "to evaluate the character of each condition as a valid syndromal entity". ${ }^{7}$ According to Stuart A Kirk and Herb Kutchins in their 1992 monograph The selling of DSM, the publication of DSM-III in 1980 "received unprecedented attention and is widely believed to have marked a milestone in American psychiatry. In influence alone, it may be one of the most significant events in psychiatry in the last half of the 20th century". ${ }^{7}$ DSM-III added over 100 new psychiatric diagnoses not listed in DSM-II, including tobacco dependence and tobacco withdrawal. ${ }^{8}$

Reviews of internal tobacco industry documents reveal that between 1976 and 1980, tobacco corporations, including Philip Morris (PM) and British American Tobacco (BAT) sought to influence the APA task force revising the DSM. These efforts occurred through prominent psychiatrists who lobbied APA officials regarding the definitions of tobacco related disorders in DSM-III without disclosing their links to the tobacco industry. The inclusion of tobacco related disorders at all in DSM-III represented the failure of this surreptitious tobacco industry campaign to influence the editorial process of the DSM-III. However, industry lobbying attempted to influence the editorial process of DSM-III, and may have contributed to a narrowing of the definition of tobacco dependence over serial drafts of the manual. Ultimately, DSM-III defined tobacco dependence in a way that limited the practical applicability of the diagnosis and failed to support smoking cessation as a standard medical treatment to be implemented for all chronic smokers. Our review of the documents suggests that, following the publication of the DSM-III, the tobacco industry and its allies coordinated efforts to challenge the DSM-III definition of tobacco dependence. These efforts included public

Abbreviations: APA, American Psychiatric Association; BAT, British American Tobacco; B\&W, Brown and Williamson; CTR, Council for Tobacco Research; DSM-III, Diagnostic and statistical manual of mental disorders, third edition; ICD-9, International classification of disease, ninth revision; NIDA, National Institute on Drug Abuse; PM, Philip Morris; RJR, RJ Reynolds; TI, Tobacco Institute; TIRC, Tobacco Industry Research Committee 
statements aimed at discrediting tobacco dependence as a psychiatric diagnosis and continued lobbying of APA officials by individuals with undisclosed tobacco industry ties. Further, tobacco companies contracted with behavioural scientists to produce conferences and a monograph and intended to challenge the DSM-III. This effort may have further blunted the practical impact of including even the restricted definition of tobacco dependence that was included in DSM-III.

\section{METHODS}

Between March and August 2003, we searched tobacco industry document internet sites (University of California San Francisco Legacy Tobacco Documents Library http:// legacy.library.ucsf.edu/ and British American Tobacco (BAT) collection www.library.ucsf.edu/tobacco/batco; Philip Morris www.pmdocs.com). Searches began with general terms such as "Psychiatry", "American Psychiatric Association", and "DSM" and then were expanded using Boolean operators such as "AND" and "OR" to include names, locations, dates, and reference (Bates) numbers.

Additional information was collected through discussions with psychiatrists familiar with the editorial process surrounding DSM-III, and online searches of Lexis-Nexis Academic Universe (http://www.lexis-nexis.com/), Medline, and general internet searches (Google).

\section{RESULTS}

\section{Historical context: definitions of tobacco dependence} before DSM-III

In preparing the DSM-III, a stated goal of the APA Task Force on Nomenclature and Statistics was to correlate the diagnoses listed in DSM-III with the ninth revision of the World Health Organization's International classification of disease (ICD-9). . ICD-9 appeared in 1977 and included tobacco dependence as a diagnostic category. ${ }^{9}$

While ICD-9 acknowledges the addictive potential of tobacco, it separates tobacco dependence from other drug dependence disorders for the absence of a pronounced psychotoxic effect associated with tobacco. ICD-9 defines drug dependence broadly in code 304 as:

A state, psychic and sometimes also physical, resulting from taking a drug characterized by behavioral and other responses that always include a compulsion to take a drug on a continuous or periodic basis in order to experience its psychic effects, and sometimes to avoid the discomfort of its absence. ${ }^{10}$

ICD-9 makes a special note that while this definition applies to most psychotropic drugs, it does not apply to tobacco dependence. Tobacco dependence appears, paradoxically, under code 305, "Non-dependent abuse of drugs", which includes cases:

Where a person, for whom no other diagnosis is possible, has come under medical care because of the maladaptive effect of a drug on which he is not dependent and that he has taken on his own initiative to the detriment of his health or social functioning. ${ }^{10}$

Tobacco dependence is specifically defined under code 305.1:

Cases in which tobacco was used to the detriment of a person's health or social functioning or in which there is tobacco dependence. Dependence is included here rather than under 304 because tobacco differs from other drugs of dependence in its psychotoxic effects. ${ }^{10}$

The WHO's ICD-9 was adopted for use in the USA in 1980 as the ICD-9-Clinical Modification with these same tobacco related codes intact. ${ }^{11}$

Writing in the 1977 National Institute on Drug Abuse (NIDA) monograph Research on smoking behavior, Jerome Jaffe, MD, a consultant for the DSM-III section on tobacco use disorders, described the separation of tobacco from other drugs of abuse as reflecting a "peculiar ambivalence" regarding the status of tobacco as an addictive drug on the part of the world psychiatric community in the late 1970s. ${ }^{12}$ He noted that while tobacco was at the time viewed as a potentially addictive substance,

There was significant controversy...about whether even heavy smoking could be properly viewed as a mental disorder if, despite the medical risks, the smoker states that he or she is satisfied to be a smoker, since, unlike the ingestion of alcohol, tobacco does not produce obvious disability or impairment of mental function. ${ }^{12}$

Nonetheless Jaffe noted that:

...by 1975 it had become evident that the forthcoming version of the American Psychiatric Association's Diagnostic and Statistical Manual, DSM-III, could not continue to ignore excessive or compulsive tobacco using behavior... The decision to include some forms of tobacco use in DSM-III was far less difficult than the problems of where to include them and how to differentiate those varieties of tobacco use that do not represent 'mental disorders' from those that do. ${ }^{12}$

\section{Tobacco industry attempts to influence the editors of DSM-III}

In 1974, the APA appointed a Task Force on Nomenclature and Statistics, chaired by Robert L Spitzer of the Columbia College of Physicians and Surgeons to develop DSM-III; they presented the first draft of the DSM-III at a special session of the APA annual meeting in May 1975. Over the course of its development, serial revisions of DSM-III were discussed at regional and national meetings of the APA. Additionally, beginning with the April 1977 draft of DSM-III, the APA published serial revisions of the manual for critical review by the association's members. ${ }^{8}$

The tobacco industry carefully monitored the creation of the DSM at high levels within its scientific and political operations. In a memorandum dated 28 October 1976, William L Dunn, principal scientist at PM, wrote to Helmut Wakeham, PM vice president for science and technology, Robert Seligman, PM vice president for research and development, Thomas Osdene, PM director of research, Raymond Fagan, principal scientist at PM Research Center, Richmond, VA, and PM scientist Robert Carpenter. Dunn describes PM's surveillance of the APA and the revisions of DSM then occurring:

The attached [1976 draft of the DSM-III definition of "Tobacco Use Disorder"] has been excerpted from the working draft of the Task Force on Nomenclature and Statistics of the American Psychiatric Assn. The task force comprises 80 people, mostly psychiatrists, chaired by Robert Spitzer of the New York State Psychiatric Institute. Jerome Jaffe, New York State Psychiatric Institute is 
designated a special consultant on the section on tobacco use disorder, and probably wrote the two pages. Unless dissuaded otherwise, the Task Force is expected to add the diagnosis of tobacco use disorder in the Third Edition of the Diagnostic and Statistical Manual of the American Psychiatric Assn. To be published probably in the second half of 1977.

Please treat this material in strictest confidence. It is from a progress report that is not a public document. ${ }^{13}$ [emphasis added]

The attachment includes the 1976 draft of the DSM-III definition of "tobacco use disorder" (table 1).

Horace R Kornegay, president of the Tobacco Institute (TI), the tobacco industry's Washington DC based lobbying and political arm, shared the concerns of PM's scientific establishment regarding the inclusion of tobacco related disorders in DSM-III. In a memorandum to the TI's high level Committee of Counsel, a secret committee that consisted of the head lawyers of the tobacco companies and some other high level officials, ${ }^{14}$ dated 4 November 1976, Kornegay outlines his concerns. (Note that he erroneously refers to the pending revision of the DSM as the "second edition" and the proposed diagnosis as "compulsive smoking syndrome".)

We have learned that the American Psychiatric Association will be adding "compulsive smoking syndrome" to its Diagnostic and Statistical Manual....

A Group of 80 psychiatrists are currently working on the second edition of the manual, perhaps at the association's Washington office. Committee includes Jerome Jaffee [sic] New York State's Chief Psychiatrist, who first (to our knowledge) proposed this step at the Third World Conference in June 1975....

If tobacco abuse is classified as a mental health syndrome, as drug abuse is, the cost of cessation clinics would be covered by any health insurance contract that includes treatment of mental illness. Further, official recognition of smoking as an "abuse" stigmatizes cigarette smokers as a class along with those who use illicit drugs....

We do strongly believe that this is a matter of sufficient importance to be called to the attention of the [Tobacco Institute] member companies. ${ }^{15}$
In a subsequent memorandum to the Committee of Counsel dated 18 November 1976, Kornegay outlines the TI strategy aimed to influence the editorial process of DSM-III:

As a follow-up to my memorandum of November 4 to the Committee of Counsel calling attention to the fact that the American Psychiatric Association has under consideration the adding of "Compulsive Smoking Syndrome" to its Diagnostic and Statistical Manual, I am pleased to advise that Dr. Richard Proctor, chairman of the department of psychiatry at Bowman Gray Medical School, has agreed to write a substantial number of his colleagues to object to this undertaking. The matter was called to Dr. Proctor's attention by Colin Stokes of RJR [RJ Reynolds Tobacco Company] and after talking with Mr. Stokes, Dr. Proctor is in full agreement that such a classification should not be included in the Diagnostic and Statistical Manual of the APA.

Hopefully, the officers and directors of other companies are taking a similar interest to discourage this move by the APA. ${ }^{16}$

Richard Proctor was professor and chairman of the Department of Psychiatry at the Bowman Gray School of Medicine in Winston-Salem, North Carolina from 19621985. ${ }^{17}{ }^{18}$ He worked extensively for RJR and other tobacco companies as a researcher, consultant, and advisor through the 1980s. Proctor first contacted the tobacco industry's Tobacco Industry Research Committee (TIRC) in December 1956, while an assistant professor in Psychiatry at Bowman Gray, ${ }^{17}$ to request application blanks for a research grant. ${ }^{19}$ Although Proctor's application was subsequently denied, ${ }^{20}$ Proctor ultimately did receive tobacco industry funding as a researcher and consultant. A letter dated 29 October 1979 from Proctor to Timothy M Finnegan of the offices of the tobacco industry law firm Jacob and Menninger lists "the preliminary budget we discussed today", totalling \$32 000 for a "proposed tobacco/drug study". ${ }^{21}$ An unsigned RJR document entitled "R\&D Personnel Acquisitions, 1977-1987" states that "At present, we are utilizing the consultant services of Dr. Richard C. Proctor (Bowman Gray School of Medicine $)^{\prime \prime}{ }^{22}$ Jacob and Menninger helped manage secret

Table 1 Changes in diagnostic criteria for tobacco dependence in DSM-III, 1976-1980

\begin{tabular}{|c|c|c|}
\hline DSM-III draft, March $1976^{38}$ & DSM-III draft, January $1978^{61}$ & DSM-III, $1980^{8}$ \\
\hline $\begin{array}{l}\text {...the use of tobacco is considered } \\
\text { here as a disorder only when it } \\
\text { fulfils the following criteria: } \\
\text { (1) The use of the substance is } \\
\text { directly associated with either } \\
\text { distress at the need to repeatedly } \\
\text { take the substance or, } \\
\text { (2) It directly produces signs or } \\
\text { symptoms, usually of a physical } \\
\text { nature, which would remit, at } \\
\text { least in part, on cessation of } \\
\text { tobacco use }\end{array}$ & $\begin{array}{l}\text { Diagnostic criteria for tobacco use } \\
\text { disorder } \\
\text { Either (1) or (2): } \\
\text { (1) The individual experiences distress } \\
\text { at the need to use tobacco repeatedly } \\
\text { (2) Both (a) and (b): } \\
\text { (a) A serious physical disorder in which } \\
\text { smoking is a significant etiological or } \\
\text { exacerbating factor; and } \\
\text { (b) Evidence of current physiological } \\
\text { dependence on tobacco or nicotine } \\
\text { either by the presence of tobacco } \\
\text { withdrawal or by the daily intake of } \\
\text { nicotine of sufficient magnitude that } \\
\text { the diagnostician judges that the } \\
\text { withdrawal syndrome would ensue } \\
\text { if the intake of tobacco stopped for } \\
\text { more than } 24 \text { hours }\end{array}$ & $\begin{array}{l}\text { Diagnostic criteria for tobacco } \\
\text { dependence } \\
\text { (A) Continuous use of tobacco } \\
\text { for at least one month } \\
\text { (B) At least one of the following: } \\
\text { (1) Serious attempts to stop or } \\
\text { significantly reduce the amount } \\
\text { of tobacco use on a permanent } \\
\text { basis have been unsuccessful } \\
\text { (2) Attempts to stop smoking } \\
\text { have led to the development of } \\
\text { tobacco withdrawal... } \\
\text { (3) The individual continues to } \\
\text { use tobacco despite a serious } \\
\text { physical disorder (e.g. } \\
\text { respiratory or cardiovascular } \\
\text { disease) that he or she knows is } \\
\text { exacerbated by tobacco use }\end{array}$ \\
\hline
\end{tabular}


"special projects" funded through TIRC that bypassed TIRC's nominal scientific peer review process and instead awarded and managed by lawyers to meet the tobacco industry's political and legal needs. ${ }^{23}$

In a memorandum of 10 June 1981, RJR director GB Whitaker informed FH Christopher, RJR senior vice president of manufacturing that:

On several occasions in the past, our Company has engaged the services of Dr. Richard C. Proctor of the Bowman Gray School of Psychiatry, once for a seminar in the Research Department at which over 100 people were in attendance, and several times for conferences with Marketing and Brand Personnel. ${ }^{24}$

Whitaker goes on to express concern over his discovering that "Dr Proctor will be in Richmond two days next week talking to our competitors". ${ }^{24}$

In response to Christopher's concerns, a handwritten note appears at the bottom of the memorandum, signed by "Alan", an unidentified author:

I talked with George [Whitaker] and allayed his fears that Dr. Proctor might be advising a competitor of RJR. I told George of some of the things that Dr. Proctor has done on behalf of the whole tobacco industry. ${ }^{24}$

As indicated by Horace Kornegay of the Tobacco Institute, Proctor voiced strong opposition to the inclusion of tobacco dependence in DSM-III through an extended correspondence with Robert L Spitzer, chairman of the task force revising DSM-III. Copies of these letters were located in the tobacco industry documents; in them, Proctor never indicates any connection with the tobacco industry. However, "Mr. Colin Stokes, Chairman, R.J. Reynolds Tobacco Company" is listed as a blind copy recipient in the first of the available letters, dated 7 December 1976. In this letter, Proctor argues against the proposed DSM definition of "tobacco use disorder", comparing it to the criteria used to define obesity as a medical disorder. Proctor argues "on the one hand, you are talking about a process - tobacco use disorder and on the other hand, a result of the process-obesity.... It appears to me that you are not using the same criteria" in the definition of disorders. ${ }^{25}$ In a subsequent letter to Spitzer, Proctor continues similar arguments: "I am concerned that you are not using the same game plan and the same rules on food and excessive eating that you use on the use of tobacco." ${ }^{26}$ In response, Spitzer argues that "we are consistent in the rules that we apply to excessive eating and the use of tobacco", going on to state that:

Tobacco use is only considered a disorder when the patient is distressed by the craving for tobacco or when it directly causes physical symptoms. Thus, tobacco use is considered a disorder when it directly causes some distress to the individual.... very much appreciate your letters on this subject as it has helped sharpen our thinking on this very difficult area. I would appreciate hearing from you again in response to this letter. ${ }^{27}$

Proctor's correspondence with Spitzer continued through the completion of DSM-III. A letter from Spitzer to Proctor dated 4 May 1979 found in tobacco industry files included "the latest, and hopefully the final, draft of Tobacco Dependence.... We look forward to meeting you in Chicago. I apologize for getting this material to you so late...."28 Proctor himself forwarded a number of the DSM-III drafts sent him directly to Frank G Colby, manager of the RJR Scientific Information Division. ${ }^{29}{ }^{30}$ In a letter to Proctor dated 21 June 1979, Colby writes:

Thank you very much for your two notes of May $15^{\text {th }}$ and the attached material from the American Psychiatric Association... It is not clear to me whether the latest definition is simply another draft or whether it will be printed as is in the "Manual. ${ }^{\prime \prime 1}$

Proctor also made public statements against the inclusion of tobacco dependence as a DSM-III diagnosis. An article entitled "Who's Mentally Ill?" in the January 1978 issue of the US magazine Psychology Today quotes Proctor extensively. ${ }^{32}$

Richard Proctor, a psychiatrist in Winston-Salem, North Carolina, commented, tongue in cheek: "Since I use both tobacco and coffee, I hope that my hospital insurance and all of the other third-party carriers will cover the cost of hospitalization and treatment if I decide I would like to stop.... I trust that, too, when the DSM-IV is compiled, missing a three-foot putt on the $18^{\text {th }}$ hole will be classified as a psychiatric diagnosis. It would make about as much sense as the tobacco or caffeine classifications. ${ }^{32}$

The tobacco documents also contain a letter from New York psychiatrist and author ${ }^{26}$ Leonard Cammer. In a letter to Spitzer on 17 January 1977, Cammer argues against the inclusion of tobacco dependence as a DSM-III diagnosis. Richard C Proctor is listed as a carbon copy recipient of the letter. Cammer argues that:

You and Dr. Jaffe present a cogent rationale for including Tobacco Use Disorder (TUD) in DSM III. Yet it is my opinion that it does not really stand.... It seems that psychiatry has been overextended, reaching into areas that might be better left to educators and some categories of psychologists, ecologists, sociologists, and social workers. Physicians can and must treat the consequences of all endogenous and exogenous stresses on the human machinery but it cannot treat the conflicts of the world itself. $^{33}$

We have not found any evidence in the tobacco documents of involvement between Cammer and the tobacco industry.

John Schwab, MD, is listed an additional addressee of a letter from to Proctor containing revisions of "Tobacco Dependence". ${ }^{28}$ Schwab is listed as having received \$255 from the Council for Tobacco Research (CTR) Special Account 4 in 1985 for "consultation fees, expenses, and special project funding". ${ }^{34}$ (In 1964, the TIRC was renamed CTR. ${ }^{2}$ ) As noted above, CTR special accounts were managed by tobacco industry law firms to fund projects intended to cast doubt on the relationship between smoking and adverse health events and serve other legal and political needs of the industry. ${ }^{23}$

The tobacco industry also monitored professional debates within the behavioural sciences surrounding DSM-III. PM documents contain a letter from Maurice Lorr, professor of psychology at the Catholic University of America in Washington DC to Arthur Centor of the American Psychological Association's Professional Affairs Office. Lorr, reporting on a 1976 DSM-III planning conference, voices concern that the DSM-III would define "psychiatric disorders as medical disorders (diseases) in which the presenting symptoms or manifestations are psychological rather than physical [emphasis in original]". ${ }^{35}$ 
Since it will be a while before the Committee can complete DSM-III and gain approval from their council, there is time for exerting some pressure. As I see it lawyers, judges, and third party agency heads will see these disorders listed as diseases.... Obviously this will place clinical psychologists and many others under pressure to prove why they should be practicing without psychiatric supervision. So something needs to be done. ${ }^{35}$ [emphasis in original]

Centor subsequently forwarded Lorr's letter to the American Psychological Association's Board of Professional Affairs and Committees on Health Insurance, State Legislation, Professional Standards Review, and Standards:

Enclosed is a letter from Maury Lorr.... His observation that we do have an opportunity to affect what goes into DSM-III should motivate us to plan strategy and carry it out. The way to lessen threats of "medical psychotherapy" issues is to pursue a plan as suggested by Maury. ${ }^{36}$

We have found no evidence that demonstrates that Philip Morris or other tobacco companies sought an alliance with the American Psychological Association or its members to attempt to influence DSM-III. After the publication of DSMIII in 1980, however, Theodore H Blau, PhD, president of the American Psychological Association in 1977, received $\$ 120000$ from 1981-86 from lawyer managed CTR Special Account 4 for "analysis and evaluation of research on the tobacco habit"".2

In 1982, Blau testified before a Congressional subcommittee on the definition of nicotine addiction. An RJR summary of his testimony reported:

In reviewing my experience with the thousands of people that I have seen professionally, many of whom were heavy smokers, I find some continued, some quit with stress, and some quit with little or no stress. These patients of mine in no way acted like the patients that I have seen who struggle to be released from addictions of opiates or alcohol or amphetamines....although cigarette smoking is a common and pervasive habit, I can find no convincing basis in the scientific literature or in my own professional clinical experience to justify labeling it or treating it like an addiction. ${ }^{37}$

\section{Changes in DSM-III definitions of tobacco related disorders}

Ultimately, the DSM-III included definitions of "tobacco dependence" and "tobacco withdrawal" as psychiatric diagnoses. Although this diagnostic distinction has been preserved to the current version (as of March 2005) of the DSM, the majority of our findings concern the creation of tobacco dependence as a psychiatric diagnosis and do not refer to the process surrounding the definition of tobacco withdrawal by the APA. The definition of tobacco dependence as a DSM-III diagnosis underwent important revisions that substantially narrowed its scope between its initial proposal in March 1976 and the version published in DSM-III in 1980. Table 1 compares two draft versions and the final version of the diagnostic criteria for tobacco dependence.

In the earliest draft available of "tobacco use disorder", from 1976, the diagnosis includes all smokers expressing "distress" at the need to smoke, or experiencing "signs or symptoms" associated with tobacco smoking, such as:

cough due to bronchial irritation, shortness of breath on exertion due to decreased vital capacity or high levels of carbon dioxide in the blood; and pain on exercise, either due to coronary artery disease or peripheral vascular disease. In addition, a variety of non-specific symptoms, such as fatigue, anxiety, insomnia, irritability, difficulty in concentrating, palpitations, arrhythmia, headaches, gastro-intestinal distress, may show substantial reduction or disappear when prolonged tobacco use is discontinued. ${ }^{38}$

The final version of DSM-III in 1980 shows significant narrowing from the initial $1976 \mathrm{draft}$ (table 1). The initial draft required only tobacco use; the final version required a minimum duration of tobacco use of at least one month, and a specific requirement was added that the patient had already made unsuccessful but "serious attempts to stop" with development of withdrawal symptoms. Further, the necessary physical consequences of tobacco smoking required for the diagnosis increased from "signs or symptoms, usually of a physical nature, which would remit, at least in part, on cessation of tobacco use" to the presence of "a serious physical disorder (e.g. respiratory or cardiovascular disease)". ${ }^{8}$ The introductory definition of tobacco dependence in DSM-III further specifies the clinical context in which the diagnosis could be made:

In practice this diagnosis will be given only when either the individual is seeking professional help to stop smoking, or, in the judgment of the diagnostician, the use of tobacco is seriously affecting the individual's physical health. It should also be noted that a heavy smoker who has never tried to stop smoking, who has never developed Tobacco Withdrawal, and who has no tobacco-related serious physical disorder, according to the criteria in this manual, does not have the disorder of Tobacco Dependence, even though physiologically the individual is almost certainly dependent on tobacco. ${ }^{8}$

Thus, by DSM-III criteria, the state of being dependent on tobacco is insufficient in itself to support the diagnosis of tobacco dependence. In an appendix to DSM, the editors indicate possible reasons for their strategy in classifying tobacco dependence, which differs in DSM-III from the descriptions of other substance dependence states:

The justification for the inclusion of Tobacco Dependence in DSM-III... rests in the serious medical complications of long-term use....It could be argued that the absence of both an intoxication state and the kinds of social complications associated with other substances of dependence speak for classifying Tobacco Dependence as a physical disorder, not a mental disorder. However, the behavioral manifestations of the dependence (inability to control use) and the withdrawal syndrome are by no means inconsequential. ${ }^{8}$

In a separate article, Jerome Jaffe, MD, the DSM-III consultant for tobacco related disorders, acknowledges that the DSM-III criteria for tobacco dependence "lead to certain unusual inconsistencies":

For example, an individual who is a heavy smoker and who has no tobacco related medical problems may deny concern about smoking. That individual, at that moment, does not have Tobacco Use Disorder. Should the same individual express concern about an inability to stop smoking, the behavior would meet the criteria for a disorder. Denials of concern by individuals dependent on 
alcohol or opiates are disregarded in the diagnosis of alcoholism or opiate addiction... Indeed, denial is often viewed as a hallmark of drug dependence problems. Under the criteria to be used in DSM-III, there will be many heavy smokers who are obviously dependent on tobacco but who deny concern or interest in cessation and who will not be diagnosed as having Tobacco Use Disorder. ${ }^{12}$

The final DSM-III definition of tobacco dependence is thus more limited in scope than the definition proposed in the original draft of DSM-III. The revised definition distinguishes tobacco from other drugs of abuse because of its lack of an intoxicating effect and its wide social acceptance.

\section{Tobacco industry actions following the publication of DSM-III}

According to the documents that we have reviewed, tobacco industry executives viewed the inclusion of even this restricted definition of tobacco dependence in DSM-III as a major adverse event. A memorandum dated 18 June 1981 from Ernest Pepples, senior vice president and general counsel for Brown and Williamson (B\&W), to B\&W chairman and CEO Dr Ivor W Hughes and Charles I McCarty, chairman and chief operating officer of BAT, B\&W's parent company, listed "'plus' and 'minus'... smoking and health events over the past few years". ${ }^{39}$ In his list of 20 "minus" events, Pepples lists "inclusion of tobacco in DSM-III under "tobacco use disorder"'. ${ }^{39}$

After the publication of DSM-III in 1980, documents suggest that tobacco industry officials continued to attack the inclusion of tobacco dependence as a psychiatric diagnosis. On 8 December 1980, William D Toohey, Jr of the TI circulated a memorandum to spokespeople with the "TI statement in response to American Psychiatric Association Policy DSM-III describing tobacco smoke [sic] as an 'Organic Mental Disorder"':

It's certainly controversial for the APA to describe a personal behavior of nearly $40 \%$ of the U.S. adult population as a mental disorder. It is important to note that well respected scientists have criticized the DSM-III position on tobacco smoking. They maintain that it is a common personal behavior. We doubt that many psychiatrists will view this position as anything more than another antismoking ploy. ${ }^{40}$

The TI statement used a standard industry approach in characterising medical or scientific developments that were adverse to the industry's interests as "controversial". In a footnote titled "FYI-not for general discussion", Toohey notes that the "well respected scientists" that the TI statement refers to include "Dr. Richard Proctor of Winston-Salem ${ }^{5}$ Dr. John Schwab of Louisville", ${ }^{40}$ both recipients of lawyer controlled tobacco funding as described above.

Proctor continued to voice opposition to the inclusion of tobacco related disorders in DSM-III following its publication. In a letter dated 22 October 1980, Proctor contacted George Tarjan, president-elect of the APA at the time.

I very much enjoyed talking with you at the meeting of the Southern Psychiatric Association... I continue to be somewhat concerned about the DSM III conclusion of "tobacco withdrawal" and "tobacco dependence." As you probably know, I opposed this several years ago when the DSM III was first being considered. For your information, I am enclosing some correspondence that I had with Dr. Spitzer concerning this and some replies I had....

As I mentioned in the letters and as I also mentioned to you, it is beginning to cause some insurance problems. I know of some individuals who are claiming that they are disabled because they use tobacco and consequently are filing for disability through social security and through private insurance carriers. I also know of some individuals who have been hospitalized and are at present involved with their insurance carriers claiming that since tobacco use is listed as an "illness" their insurance has to cover the cost of hospitalization and treatment.

But, I am particularly concerned about what's going to happen in the future, with the inclusion for tobacco use and tobacco dependence, and caffeine use, I can visualize hearings in Congress when a question of insurance coverage for psychiatric problems is debated. I can right now see a Georgia congressman-as you know Coca Cola's home office is in Atlanta-saying on the floor of Congress that it is difficult to cover psychiatric problems since psychiatrists say that smoking, using tobacco, drinking Coca Cola is a mental illness and homosexuality is normal. I feel we have enough problems with public relations in psychiatry at present without asking for this. ${ }^{41}$

Proctor's letter reflects common tobacco industry arguments about the "slippery slope" of regulation; namely that even limited restrictions on smoking behaviour could lead to more widespread consequences.

Proctor's letter to Tarjan of 22 October does not reveal his financial ties to the tobacco industry. In a response to Proctor dated 18 November 1982, Tarjan appears not to know of Proctor's tobacco industry connections:

I indeed enjoyed reading the correspondence between you, Leonard Cammer and Bob Spitzer on tobacco, and caffeine use and dependence. I hope someone keeps a historical file on these matters because I wonder how historians might ultimately view our contortions around these types of diagnostic issues. ${ }^{42}$

Proctor also wrote to Gary L Tischler, then professor and chairman, Department of Psychiatry at Yale University, participant in an APA sponsored conference to evaluate DSM-III, and editor of Diagnosis and classification in psychiatry, the 1987 monograph published in association with the conference. ${ }^{43}$ Proctor's letter of 24 January 1983 reads:

I am writing you in regard to the revision of DSM III. I continue to be concerned with the inclusion of "tobacco use disorder" ... I think we have to be aware of political issues. It is interesting to me that the term "tobacco use disorder" would also include the use of snuff and chewing tobacco. As you well know, not even the surgeon general has condemned those two and both are still advertised extensively on television. I would hate to be the one to tell Terry Bradshaw, the quarterback of the Pittsburgh Steelers, that his use of chewing tobacco indicates mental illness.... ${ }^{44}$

As it has done in many other areas, such as secondhand smoke, ${ }^{45} 46$ the tobacco industry also contracted with psychiatric researchers to coordinate conferences and publications designed to stimulate controversy surrounding DSMIII. At least one of these projects was funded through a CTR lawyer controlled Special Account. ${ }^{23}$ 
An 8 November 1978 memorandum from Edwin J Jacob ${ }^{47}$ of the law offices of Jacob and Medinger, which managed the CTR special accounts, describes a two year, $\$ 400000$ proposal for "analysis of policy in issues dealing with control and regulation of routine behavior in a democratic society" ${ }^{\prime 48}$ by Alfred M Freedman, MD, and Richard Brotman, PhD. Freedman was professor and chairman of the Department of Behavioral Sciences at New York Medical College and coeditor of an influential textbook of psychiatry. ${ }^{49}$ Brotman was professor of psychiatry at New York Medical College. William W Shinn, of Shook, Hardy, and Bacon, the tobacco industry law firm that focused on scientific, political, and product liability issues for the industry, subsequently forwarded the proposal to Henry C Roemer, vice president and general counsel for RJR, ${ }^{50}$ as well as to Thomas F Ahrensfeld, vice president and general counsel for PM: ${ }^{51}$

You will be receiving a brief letter from Ed Jacob recommending support for a project proposed by Drs. Richard Brotman and Alfred Freedman.... Drs. Brotman and Freedman are both familiar with the course of events leading to the inclusion of "tobacco use disorder" and "tobacco withdrawal" in DSM-III. Their proposal, however, is broad gauge and would seek out timely public issues for discussion by a variety of individuals in the behavioral sciences and related fields.... They are philosophically opposed to prohibition other unwarranted intrusions into individuals' choices of behavior. ${ }^{51}$

Shinn mentions "prohibition", a term commonly used in tobacco industry documents to describe efforts designed to reduce smoking.

A listing of CTR Special Projects dated l April 1982 includes Drs Brotman and Freedman as having been approved in June 1979. To carry out their proposed project, Freedman and Brotman would establish the Center for Behavioral Analysis of Policy Issues, later renamed the Madison Institute for Policy Research and Development. ${ }^{52}$ This project was funded from CTR Special Account 5, ${ }^{48}$ with money from the American, Brown \& Williamson, Lorillard, Philip Morris, and RJR tobacco companies. ${ }^{52}$

In February 1982, Brotman and Freedman again approached the tobacco industry for funding:

...to conduct, over a one-year period, six 'mini-conferences' culminating in an international conference. The purpose of these conferences will be to explore "critical issues in psychiatric classifications which have arisen as a result of DSM III...and which must be addressed in connection with DSM IV.... A monograph will be prepared following the international conference. ${ }^{52}$

A 1986 report from the law offices of Shook, Hardy, and Bacon lists Brotman and Freedman as approved in October 1982 to receive $\$ 237000$ from CTR Special Account $5 . .^{53}$ Their project would analyse "policy in issues dealing with the control and regulation of behavior in a democratic society", with a "proposed publication date of conference papers, November 1986 by Human Services Press". ${ }^{53}$ The resulting monograph, entitled Issues in psychiatric classification: science, practice and social policy, published by Human Sciences Press, appeared in 1986, and does not include reference to any tobacco companies or CTR as sources of funding. Rather, the monograph was described as being:

...based on an International Conference on Critical Issues
in Psychiatric Classification, held in New York City,
February 3-5, 1984, sponsored by the Dept. of Psychiatry and the Center for Comprehensive Health Practice of New York Medical College. ${ }^{54}$

The introduction to the monograph describes the basic goals of the conference:

The agenda did not call for arguments about particular diagnostic categories. Instead, it was concerned with the general principles that should guide the development of a psychiatric nosology and also the many different interests in society that are affected by how that is done. ${ }^{54}$

As the tobacco industry generally does in its efforts to influence scientific and clinical discourse, ${ }^{55}$ the classification of tobacco dependence is not a primary focus of the monograph. However, smoking is mentioned several times in the text in arguments consistent with industry stances. In an edited transcript of a conference discussion period included in the monograph, Richard Brotman cites the example of smoking tobacco as follows. Addressing a Greek psychiatrist attending the conference, Brotman states:

Dr. Stefanis... in the business of drug addiction, I hope we don't transmit to you.... all the mistakes that we have made by having a DSM that now details more things like drug addiction, smoking, cocaine, and maybe loud noises that come from the radios of the Spanish kids that walk along the streets.... ${ }^{54}$

As Brotman goes on to argue, "the real question for us is...why do we keep including more things, that I would refer to as routine behavior, into orders of classification, invoicing supposedly not-so-routine or abnormal or deviant behavior". ${ }^{54}$ To Brotman, the inclusion of tobacco dependence, and more broadly, drug addiction, in DSM-III is a concerning example of a trend towards blurring the distinction between providing therapy for psychiatric disorders and the control of aberrant behaviour in society.

\section{Definitions of tobacco dependence in DSM-III-R and DSM-IV}

Despite the lobbying efforts of the tobacco industry and allied parties before and following the publication of DSM-III, subsequent revisions of the DSM show a progressive recognition of nicotine's status as a drug of abuse, grouping the diagnostic criteria for tobacco dependence with those for other substance dependence disorders. While the industry was thus unable to prevent the widespread acceptance of tobacco dependence as a disorder, such understanding may have occurred earlier among psychiatrists and the public without the industry's lobbying effort surrounding DSM-III.

DSM-III-R represented a significant departure from the discussion of tobacco related disorders in DSM-III, where, in contrast to other drugs of abuse, evidence of dependence alone was inadequate to justify the diagnosis of tobacco dependence. ${ }^{12}$ In DSM-III-R, nicotine dependence is included under the category of "psychoactive substance dependence". DSM-III-R provides specific data on patterns of use, associated features, course, impairment, complications, prevalence, sex ratio, and familial patterns for the diagnosis of nicotine dependence. However, the diagnostic criteria presented in DSM-III-R pertain to "psychoactive substance dependence" as a general category. ${ }^{56}$ These criteria include demonstration of three of a set of nine behaviours occurring over at least one month, or repeatedly over a longer period. While many of the behaviours listed do not pertain to 
nicotine use, the list of behaviours consistent with dependence includes: persistent desire or one or more unsuccessful attempts to cut down or control substance use; important social, occupational, or recreational activities given up or reduced because of substance use; continued use despite knowledge of having a persistent or recurrent physical, social, or psychological problem that is caused or exacerbated by the substance; marked tolerance, or need for increased amounts of the substance to achieve the desired effect; characteristic withdrawal symptoms; and frequent use of the substance to relieve withdrawal symptoms. ${ }^{56}$ DSM-III-R formally recognises nicotine as a dependence producing substance by application of the criteria already applied to other dependence producing substances (that is, heroin). Where DSM-III did not provide for the diagnosis of tobacco dependence on the basis of dependence alone, the DSM-III-R criteria allow for a formal diagnosis of nicotine dependence to be given to any patient exhibiting commonly recognised signs of dependence on tobacco.

DSM-IV, released in 1994, follows a similar pattern. Although specific information is given regarding nicotine dependence, the diagnostician is referred to general diagnostic criteria for "substance dependence" when diagnosing nicotine dependence. Many of these diagnostic criteria overlap with those presented as diagnostic criteria for "psychoactive substance dependence" in DSM-III-R, demonstrating a continued acknowledgement by the authors of the DSM of tobacco's ability to foster a state of dependence similar to any other drug of abuse. ${ }^{57}$

\section{DISCUSSION}

Writing to Richard C Proctor in 1982 regarding the APA's definition of tobacco dependence in DSM-III, George Tarjan, then president-elect of the APA, states: "I hope someone keeps a historical file on these matters because I wonder how historians might ultimately view our contortions around these types of diagnostic issues." ${ }^{\prime 2}$ Our review of previously secret tobacco documents suggests that members of the tobacco industry viewed the inclusion of tobacco dependence and tobacco withdrawal in DSM-III as major adverse events. Individual tobacco companies, working both directly and through collective action managed by the TI, TICR/CTR Special Projects, and industry lawyers, engaged in surveillance of the DSM-III editorial process and planned and implemented a strategy to influence its content and its impact following publication.

Richard C Proctor, professor and chair of psychiatry at Bowman Gray Medical School, directly lobbied the chairman of the APA Task Force on Nomenclature and Statistics in an attempt to influence the content of DSM-III. Following the publication of DSM-III, Proctor wrote letters to the presidentelect of the APA and the editor of an APA monograph on DSM voicing his concerns surrounding the manual's content. Our review of industry documents suggests that a number of these actions were carried out at the request of the RJR tobacco company and the TI. These tobacco documents do not contain any evidence that Proctor disclosed his industry ties to the APA.

Following the publication of DSM-III, CTR contracted with two US professors of psychiatry to create an academic institute focused on the examination of controversies in current psychiatric diagnosis and classification. While this research focused on broad topics concerning DSM-III, members of CTR viewed the work as pertinent to tobacco industry interests primarily for its relevance to the definitions of tobacco related disorders. Tobacco documents record disbursement of over $\$ 600000$ to fund this institute from CTR special accounts, leading to the production of a conference and monograph on issues in psychiatric

\section{What this paper adds}

The tobacco industry has known that nicotine is an addictive drug since the 1960s, but denied this fact publicly. The industry also has a well developed strategy of working through third parties to create controversy and slow public and professional understanding and acceptance of the scientific evidence that smoking and secondhand smoke cause disease.

Consistent with these strategies, the tobacco companies regarded the inclusion of tobacco dependence as a diagnosis in the Diagnostic and statistical manual of mental disorders, third edition (DSM-III) as an adverse event. They worked to influence the content of the DSM-III and to mitigate its impact following publication. These actions mirror industry tactics to influence medical research and policy in various contexts worldwide. This paper adds to the growing body of historical data outlining the patterns though which the tobacco industry has worked to undermine public health. While our study does not definitively demonstrate that the industry's efforts resulted in a change in the content of DSM-III, it shows important ways in which the editorial process of the DSM-III was placed at risk of industry influence.

classification. As published in 1986, the monograph contains no mention of industry funding.

Our review of the documents suggests that these industry strategies had the potential to influence the content of DSMIII. We do not have direct evidence that they actually did so. DSM-III distinguishes tobacco dependence from dependence on other drugs of abuse, citing the prevalence of smoking and the absence of acute "behavioral and social disability" associated with nicotine. ${ }^{12}$ This view was consistent with the prevalent opinions of the psychiatric community at the time, reflecting similar distinctions drawn between tobacco and other drugs of abuse in the WHO ICD-9 in 1977. ${ }^{10}$ Nonetheless, subsequent revisions of DSM-III (table 1) show narrowed criteria for tobacco dependence. Further, comments made by APA Nomenclature and Statistics Task Force chairman Robert L Spitzer indicate that the input from Richard C Proctor, a psychiatrist with undisclosed ties to the tobacco industry "helped sharpen our thinking on this very difficult area". ${ }^{27}$

Tobacco industry tactics to attempt to influence the DSMIII would have been consistent with prior reports on industry efforts to influence other professional practice standards in the health sciences. Through Operation Berkshire in 1977, seven international tobacco companies agreed to cooperate in promoting doubt as to tobacco's detrimental effects on health. ${ }^{58}$ Such efforts to promote doubt have resulted in programmes such as PMs' "Sound Science" and "Good Epidemiologic Practices" in the USA and Europe. ${ }^{55} 59$ These public relations campaigns sought to manipulate epidemiologic standards to prevent public health scientists from linking secondhand smoke to disease. The industry also has a long history of sponsoring symposia and publication of monographs designed to skew the scientific debate in directions favourable to the industry's position, such as in the areas of secondhand smoke ${ }^{45} 4660$

Beyond its historical importance, the tobacco industry's attempt to influence the DSM-III has implications for the process by which standards of practice are defined for psychiatry and other medical specialties. For DSM-III, Kirk and Kutchens write that "the ultimate inclusion test" for a DSM-III diagnosis "was in part political: whether the diagnosis was used with reasonable frequency [and] whether interested professionals and patient representatives offered 
positive comments about it". ${ }^{7}$ Industry efforts ultimately failed to prevent the inclusion of tobacco related disorders in DSM-III. However, it remains notable that the tobacco industry attempted to exploit this necessarily "political" component of DSM-III's creation as an opportunity to narrow the scope of the APA's definition of nicotine dependence. While the inclusion of nicotine dependence ultimately represented an important achievement for public health and psychiatry, our study shows that this achievement came despite the extensive and often covert actions of an industry that sought to undermine it.

\section{Authors' affiliations}

M D Neuman, A Bitton, S A Glantz, Center for Tobacco Control Research and Education, University of California, San Francisco, California, USA

This project was supported by National Cancer Institute Grant CA87472 .

Competing interests: none declared

\section{REFERENCES}

1 US Department of Health and Human Services. The health consequences of smoking: nicotine addiction, A report of the Surgeon General, 1988. Rockville, Maryland: Public Health Service, Centers for Disease Control, Office on Smoking and Health, 1988, (DHHS Publication No (CDC) 88-8406.).

2 Glantz SA, Slade J, Bero LA, et al. The cigarette papers. Berkeley: University of California Press, 1996.

3 Slade J, Bero LA, Hanaver P, et al. Nicotine and addiction. The Brown and Williamson documents. JAMA 1995;274:225-33.

4 Yeaman A. Implications of Battelle Hippo I \& I I and the Grifffith Filter. July 17 1963. Bates No. 1802.05. http://legacy.library.ucsf.edu/tid/xrc72d00 (Accessed April 2, 2004).

5 American Psychiatric Association. Diagnostic and statistical manual of mental disorders, 1 st ed. Washington DC: American Psychiatric Association, 1952.

6 American Psychiatric Association. Diagnostic and statistical manual of mental disorders, 2nd ed. Washington DC: American Psychiatric Association, 1968.

7 Kirk SA, Kutchins H. The selling of DSM. New York: Aldine de Gruyter, 1992.

8 American Psychiatric Association. Diagnostic and statistical manual of mental disorders, 3rd ed. Washington DC: American Psychiatric Association, 1980.

9 American Psychiatric Association. Progress report on the preparation of DSM-III. March 1976. Legacy Tobacco Documents Library. Bates No. 1003291442/1450. http://legacy.library.ucsf.edu/tid/ygv97e00 (Accessed July 30, 2003).

10 World Health Organization. International classification of diseases: manual of the International statistical classification of diseases, injuries, and causes of death, Based on the recommendations of the ninth revision conference, 1975, and adopted by the Twenty-Ninth World Health Assembly. Geneva: World Health Organization, 1977.

11 World Health Organization. International classification of diseases, clinical modification. Ann Arbor, Michigan: US National Center for Health Statistics, 1978.

12 Jaffe JH. Tobacco use as a mental disorder: the rediscovery of a medical problem. In: Jarvik ME, Cullen JW, Gritz ER, Vogt TM, West $\sqcup$, eds. Research on smoking behavior. Washington DC: US Government Publishing Office, 1977:202-217.

13 Dunn WL. [Memorandum]. October 28 1976. Legacy Tobacco Documents Library. Bates No. 1003291468. http://legacy.library.ucsf.edu/tid/ wrv97e00 (Accessed August 11, 2003).

14 France M. Inside Big Tobacco's secret war room. Business Week, 1998 June $15,134-8$

15 Kornegay HR. [Memorandum]. November 4 1976. Legacy Tobacco Documents Library. Bates No. 01403037 . http://legacy.library.ucsf.edu/tid/ hva91e00 (Accessed August 11, 2003).

16 Kornegay H. [Memorandum]. November 18 1976. Legacy Tobacco Documents Library. Bates No. 503683894. http://legacy.library.ucsf.edu/ $\mathrm{tid} /$ bwn85d00 (Accessed August 11, 2003).

17 Proctor RC. Department of Psychiatry: Historical Sketch. In. Winston-Salem, North Carolina: Bowman Gray School of Medicine Department of Psychiatry, 1983.

18 Goldberg L. Richard Proctor, psychiatrist, dies. Winston-Salem Journal November 1, 1995

19 Hockett RC. [Letter to RC Proctor]. December 28 1956. Legacy Tobacco Documents Library. Bates No. 50073471. http://legacy.library.ucsf.edu/tid/ jwa9aa00 (Accessed July 30, 2003).

20 Tobacco Industry Research Committee. Confidential Report: Scientific Advisory Board Meeting. March 10 1957. Legacy Tobacco Documents Library. Bates No. MNAT00642995/3001. http://legacy.library.ucsf.edu/ tid/ony34f00 (Accessed August 11, 2003).

21 Proctor RC. [Letter to Timothy M. Finnegan]. October 29 1979. Legacy Tobacco Documents Library. Bates No. 503645122/5123. http:// legacy.library.ucsf.edu/tid/ewr85d00 (Accessed August 11, 2003).
22 [No Author]. R\&D Personnel Acquisitions 1977-1987. 1987. Legacy Tobacco Documents Library. Bates No. 500895285/5287. http:// legacy.library.ucsf.edu/tid/piw59d00 (Accessed August 11, 2003).

23 Bero $L$, Barnes DE, Hanaver $P$, et al. Lawyer control of the tobacco industry's external research program. The Brown and Williamson Documents. JAMA 1995;274:241-7.

24 Whitaker GB. [Letter to Fh Christopher]. 1981. Legacy Tobacco Documents Library. Bates No. 502838988. http://legacy.library.ucsf.edu/tid/aja78d00 (Accessed August 11, 2003).

25 Proctor RC. [Letter to Robert L. Spitzer]. December 7 1976. Legacy Tobacco Documents Library. Bates No. 503683890. http://legacy.library.ucsf.edu/ $\mathrm{tid} / z v n 85 \mathrm{~d} 00$ (Accessed July 30, 2003).

26 Proctor RC. [Letter to Robert L. Spitzer]. January 4 1977. Legacy Tobacco Documents Library. Bates No. 503683879. http://legacy.library.ucsf.edu/ $\mathrm{tid} / \mathrm{xvn} 85 \mathrm{~d} 00$ (Accessed August 11, 2003).

27 Spitzer RL. [Letter to Richard C. Proctor]. January 11 1977. Legacy Tobacco Documents Library. Bates No. 503683878. http://legacy.library.ucsf.edu/ tid/wvn85d00 (Accessed July 30, 2003).

28 Spitzer RL. [Letter to Richard C. Proctor and John Schwab]. May 41979. Legacy Tobacco Documents Library. Bates No. 500877808. http:// legacy.library.ucsf.edu/tid/qrz59d00 (Accessed July 30, 2003).

29 [American Psychiatric Association]. Tobacco Dependence. May 41979. Legacy Tobacco Documents Library. Bates No. 500877809/7813. http:// legacy.library.ucsf.edu/tid/rrz59d00 (Accessed August 11, 2003).

30 Proctor RC. [Letter to Frank Colby]. June 22 1979. Legacy Tobacco Documents Library. Bates No. 500877791. http://legacy.library.ucsf.edu/ $\mathrm{tid} /$ Irz59d00 (Accessed July 30, 2003)

31 Colby FG. [Letter to Richard C. Proctor]. June 21 1979. Legacy Tobacco Documents Library. Bates No. 500877794. http://legacy.library.ucsf.edu/ $\mathrm{tid} / \mathrm{nrz59d00}$ (Accessed July 30, 2003)

32 Goleman D. Who's mentally ill? Psychology Today January 1978:34-41.

33 Cammer L. [Letter to Robert L. Spitzer]. January 17 1977. Legacy Tobacco Documents Library. Bates No. 503683869/3870. http:// legacy.library.ucsf.edu/tid/xso18c00 (Accessed August 11, 2003).

34 Greenspan, Yelon PC. Jacob, Medinger \& Finegan Special Account \#4. October 2 1985. Legacy Tobacco Documents Library. Bates No. 680800031/0034. http://legacy.library.ucsf.edu/tid/lwd91d00 (Accessed July 30,2003$)$.

35 Lorr M. [Letter to Arthur Centor]. June 14 1976. Legacy Tobacco Documents Library. Bates No. 1003291406/1407. http://legacy.library.ucsf.edu/tid/ kwv97e00 (Accessed August 11, 2003).

36 Centor A. [Memorandum]. June 29 1976. Legacy Tobacco Documents Library. Bates No. 1003291408. http://legacy.library.ucsf.edu/tid/ ewv97e00 (Accessed August 11, 2003)

37 [No Author]. Summary: Oral and Written Testimony Presented to U.S. Congressional Hearings in 1982. 1982. Legacy Tobacco Documents Library. Bates No. 503593592/3601. http://legacy.library.ucsf.edu/tid/dlv85d00 (Accessed August 14, 2003)

38 Task Force on Nomenclature and Statistics of the American Psychiatric Association. Progress Report on the Preparation of DSM-III. March 1976. Legacy Tobacco Documents Library. Bates No. 2015063003/3027. http:// legacy.library.ucsf.edu/tid/aup78e00 (Accessed August 11, 2003).

39 Pepples E. [Pluses and Minuses in Scientific and Political Arena Regarding Smoking]. June 18 1981. UCSF Brown and Williamson. Bates No. http:// legacy.library.ucsf.edu/tid/urb72d00 (Accessed August 11, 2003).

40 Toohey WD. [Memorandum]. December 9 1980. Legacy Tobacco Documents Library. Bates No. TIMN0153220. http://legacy.library.ucsf.edu/tid/ nnx82f00 (Accessed August 11, 2003)

41 Proctor RC. [Letter to George Tarjan]. October 22 1982. Legacy Tobacco Documents Library. Bates No. 503945953/5954. http:// legacy.library.ucsf.edu/tid/ebq75d00 (Accessed August 11, 2003).

42 Tarjan G. [Letter to Richard C. Proctor]. November 18 1982. Legacy Tobacco Documents Library. Bates No. 503945948. http://legacy.library.ucsf.edu/ $\mathrm{tid} / \mathrm{bbq} 75 \mathrm{~d} 00$ (Accessed August 11, 2003).

43 Tischler GL, ed. Diagnosis and classification in psychiatry. Cambridge: Cambridge University Press, 1987.

44 Proctor RC. [Letter to Gary L. Tischler]. January 24 1983. Legacy Tobacco Documents Library. Bates No. 503945949/5950. http:// legacy.library.ucsf.edu/tid/cbq75d00 (Accessed August 11, 2004).

45 Bero LA, Galbraith A, Rennie D. Sponsored symposia on environmental tobacco smoke. JAMA 1994;271:612-7.

46 Barnoya J, Glantz S. Tobacco industry success in preventing regulation of secondhand smoke in Latin America: the "Latin Project". Tobacco Control 2002;11:305-14.

47 Jacob EJ. [Memorandum]. November 8 1978. Legacy Tobacco Documents Library. Bates No. 1005125905. http://legacy.library.ucsf.edu/tid/ imr87e00 (Accessed August 11, 2003)

48 [No Author]. Ctr Special Projects. April 1 1982. Legacy Tobacco Documents Library. Bates No. 0346309/6316. http://legacy.library.ucsf.edu/tid/ hpp99d00 (Accessed August 11, 2003)

49 Freedman AM, Kaplan HI, eds. Comprehensive textbook of psychiatry. Baltimore: Williams \& Wilkins, 1967.

50 Shinn WW. [Letter to Henry C. Roemer]. November 10 1978. Legacy Tobacco Documents Library. Bates No. 503645038/5039. http:// legacy.library.ucsf.edu/tid/uvr85d00 (Accessed August 11, 2003)

51 Shinn WW. [Letter to Thomas F. Ahrensfeld]. November 10 1978. Legacy Tobacco Documents Library. Bates No. 1005125903/5904. http:// legacy. library.ucsf.edu/tid/hmr87e00 (Accessed August 11, 2003).

52 Finnegan TM. [Memorandum]. February 2 1982. Legacy Tobacco Documents Library. Bates No. 521029481/9484. http://legacy.library.ucsf.edu/tid/ mdy33f00 (Accessed August 11, 2003). 
53 Shook Hardy, Bacon. Special Account \#5. October 24 1986. Legacy Tobacco Documents Library. Bates No. 2015016544. http:// legacy.library.ucsf.edu/tid/tll28d00 (Accessed August 11, 2003).

54 Freedman AM, Brotman R, Silverman I, Hutson D, eds. Issues in psychiatric classification. New York: Human Sciences Press, 1986.

55 Ong EK, Glantz SA. Constructing "sound science" and "good epidemiology:" tobacco, lawyers, and public relations firms. Am J Public Health 2001;91:1749-57.

56 American Psychiatric Association. Diagnostic and statistical manual of mental disorders, 3rd ed, revised. Washington DC: American Psychiatric Association, 1987.
57 American Psychiatric Association. Diagnostic and statistical manual of mental disorders, 4th ed. Washington DC: American Psychiatric Association, 1994.

58 Francey N, Chapman S. "Operation Berkshire": the international tobacco companies' conspiracy. BMJ 2000;321:371-4

59 Yach D, Bialous SA. Junking science to promote tobacco. Am J Public Health 2001;91:1745-8.

60 Hong $M$, Bero L. How the tobacco industry responded to an influential study of the health effects of secondhand smoke. BMJ 2002;325:1413-6.

61 American Psychiatric Association. DSM-III draft. Washington DC: American Psychiatric Association, 1978.

\section{$\mathrm{ECHO}$}

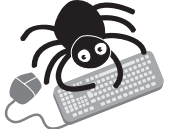

Please visit the Tobacco Control website [www. tobaccocontrol. com] for a link to the full text of this article.
Effects of neighbourhood socioeconomic status and convenience store concentration on individual level smoking

Ying-Chih Chuang, Catherine Cubbin, David Ahn, Marilyn A Winkleby

Objectives: To assess the effects of neighbourhood level socioeconomic status (SES) and convenience store concentration on individual level smoking, after consideration of individual level characteristics.

Design: Individual sociodemographic characteristics and smoking were obtained from five cross sectional surveys (1979-1990). Participants' addresses were geocoded and linked with census data for measuring neighbourhood SES and with telephone yellow page listings for measuring convenience store concentration (density in a neighbourhood, distance between a participant's home and the nearest convenience store, and number of convenience stores within a one mile radius of a participant's home). The data were analysed with multilevel Poisson regression models.

Setting: 82 neighbourhoods in four northern California cities.

Participants: 8121 women and men aged 25-74 from the Stanford heart disease prevention programme.

Main results: Lower neighbourhood SES and higher convenience store concentration, measured by density and distance, were both significantly associated with higher level of individual smoking after taking individual characteristics into account. The association between convenience store density and individual smoking was modified by individual SES and neighbourhood SES.

Conclusions: These findings are consistent with a growing body of literature suggesting that the socioeconomic and physical environments of neighbourhoods are associated with individual level smoking.

\ Journal of Epidemiology and Community Health 2005;59:568-573. 